Emir.J.Agric.Sci. (1997), 9:81- 99

\title{
Response of Tomato Growth to Foliar and Soil - Applied \\ Nitrogen Alone or With Potassium and Phosphorus. \\ I.Growth Parameters and Yield
}

\author{
Abdulkareem, M. A. and Al-Ansari, Abdul Mehdi, S, \\ Dept. of Soil Sci., College of Agriculture, University of Basrah, Iraq
}

\begin{abstract}
A field experiment was conducted during the growing season of 1993 - 1994 to compare the effect of foliar or soil applied nitrogen alone or in combination with $\mathrm{P}$ and/or $\mathrm{K}$ and the effect of spraying plants with solutions containing $\mathrm{P}(15 \mathrm{Kg} \mathrm{P} / \mathrm{ha}), \mathrm{K}(60 \mathrm{Kg} \mathrm{K} / \mathrm{ha})$ or their combination on growth and yield of tomato plants. Tomato (Lycopersicon esculentum Mill) c.v. supermarmande plants were grown in loamy sand soil under conditions favouring $\mathrm{N}$ losses from plant-soil environment. Experimental plots were trickle irrigated throughout the growing period. Plants received urea at rates of 0,60 , 120 and $180 \mathrm{~kg} \mathrm{~N} / \mathrm{ha}$ alone or in combination with $\mathrm{p}(15 \mathrm{~kg} \mathrm{p} / \mathrm{ha})$ and / or $\mathrm{k}(60 \mathrm{~kg} \mathrm{k} / \mathrm{ha})$. Each level was divided into two parts. First part was applied to plants through soil fertilization as one dose at planting time and the remaining part was applied either broadcasting or as foliar fertilization in nine applications start at flowering stage and every seven days therafter. Dry weight, plant height, and no. of flowers, fruits and branches / plant as well as early and total yield were determined. Results showed that increasing $\mathrm{N}$ rate alone or in combination with $\mathrm{P}$ and $\mathrm{K}$ beyond $60 \mathrm{~kg} \mathrm{~N} / \mathrm{ha}$ in spraying solution $(0.12 \mathrm{~mole} / \mathrm{L})$ significantly decreased growth parameters and yield. However, the highest growth parameters and yield were obtained when plants were supplied with $120 \mathrm{~kg} \mathrm{~N} / \mathrm{ha}$ through soil fertilization. The results showed that soil application of fertilizers resulted in higher growth parameters and yield than that of their respective treatments of foliar application. Nevertheless, spraying plants with N or NPK significantly increased early yield percentage as compared with soil application at all $\mathrm{N}$ rates.
\end{abstract}




\section{INTRODUCTION}

Nitrogen is one of the most important nutrient limiting crop production. Urea contains the highest $\mathrm{N}$ content of commercial fertilizers and is the cheapest dry $\mathrm{N}$ source. It is the fertilizer of choice for surface application. However, once urea is applied to soil, it is rapidly subject to biological hydrolysis by urease enzyme in soil (Fenn and Kissel, 1975). Nitrogen released from urea hydrolysis may be easily lost from the plant-soil environment through $\mathrm{NH} 3$ volatilization, $\mathrm{NO}_{3}$ losses through leaching, and by denitrification (Tomar et al., 1988). These losses may reduce the efficiency of soilapplied fertilizer $\mathrm{N}$ to be between $30-60 \%$ (Tomar et al., 1988). Plant $\mathrm{N}$ use efficiency can be improved by better timing of fertilizer application, using apporiate $\mathrm{N}$ forms or enhancing plant $\mathrm{N}$ absorption.

During the last three decades, studies on foliar nutrition of crops have received considerable attention especially under adverse soil conditions which favour nutrient losses from plant-soil environment (Malakondaiah et al., 1981; Malakondaiah and RRajeswararao, 1979). Under such conditions foliar applied $N$ could be ann alternative to soil applied $\mathrm{N}$. However; foliar $\mathrm{N}$ fertilization has not given consistent yield responses. Studies on tomato reponse to foliar fertilizer of $\mathrm{n}$ have not indicated consistent results. Das and patro (1989) and Abdul (1978) reported substantial increases in tomato plant dry weight and yield by foliar application of $n$ compared to soil application. Other studies have indicated no effect from soliar spray on tomato growth and yield (Widders, 1991, Hamar and Ver, 1972; Bestvater and Calvar, 1975).

Foliar sprays of nutrients to other crops have also given variable results. Supplemental nutrients supplied by foliar spray resulted in significant yield increase of wheat (Altman et al., 1983), soybean (Garcia and Hanway, 1976) and rice (Thom et al., 1981), had no effect on yield of soybean (Sesay and Shibles, 1980) or decreased yield of corn (Harder, 1982).

Soil properties of Al-Zubair and Safwan area (south of Iraq) is characterized by high $\mathrm{pH}$ values and $\mathrm{CaOO}_{3}$ content, low $\mathrm{CEC}$ and sandy texture. These properties may increase the potential for $\mathrm{N}$ 
losses from plant-soil environment. Thus; in order to assess the feasibility of using foliar fertilization as appropriate approach for fertilization of tomato plants grown in such soils this study was carried out. The objectivs of the study were to: 10 study the effect of different rates of $\mathrm{N}$ alone or in combination with PK on growth and chemical composition of tomato plants and 2) compare tomato plant responses to soil or foliar method of nutrients application. The effect of experimental treatments on nutrients concentration of tomato plants will be presented in subsequent paper.

\section{MATERIALS AND METHODS}

This experiment was conducted on loamy sand soil with high levels of $\mathrm{CaCO}_{3}$ and $\mathrm{pH}$ (at Al-Burjsia research station, University of Basrah, Iraq during the growing season of 1993-1994). Soil properties of the experimental site were determined according to Black (1965) and presented in table 1. The experimental plots were

Table 1. Chemical and physical properties of the soil used.

\begin{tabular}{|c|c|c|}
\hline \multicolumn{2}{|c|}{ PH $(1: 2.5)$} & 7.7 \\
\hline \multicolumn{2}{|c|}{$\operatorname{Ece}\left(\mathrm{ds} \mathrm{m}^{-1}\right)$} & 3.2 \\
\hline \multicolumn{2}{|c|}{$\mathrm{CaCo}_{3}\left(\mathrm{~g} \mathrm{~kg}^{-1}\right)$} & 80.0 \\
\hline \multicolumn{2}{|c|}{$\operatorname{CEC}\left(\right.$ Cmole kg $\left.^{-1}\right)$} & 10.70 \\
\hline \multicolumn{2}{|c|}{$\mathrm{NaHco}_{3}-\mathrm{p}(\mathrm{ppm})$} & 8.8 \\
\hline \multicolumn{2}{|c|}{ Total N. $\left(\mathrm{g} \mathrm{kg}^{-1}\right)$} & 0.3 \\
\hline \multicolumn{2}{|c|}{ Organic Matter $\left(\mathrm{g} \mathrm{kg}^{-1}\right)$} & 2.1 \\
\hline \multicolumn{2}{|c|}{ Organic Carbon $\left(\mathrm{g} \mathrm{kg}^{-1}\right)$} & 1.2 \\
\hline \multicolumn{2}{|c|}{ C:N Ratio } & 4.0 \\
\hline $\mathrm{Ca}^{++}$ & \multirow{9}{*}{ 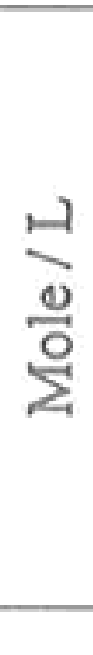 } & $544 \times 10^{-4}$ \\
\hline $\mathrm{Mg}^{++}$ & & $124 \times 10^{-3}$ \\
\hline $\mathrm{Na}^{+}$ & & $162 \times 10^{-5}$ \\
\hline $\mathrm{K}^{+}$ & & $85 \times 10^{-5}$ \\
\hline $\mathrm{Co}^{=}$ & & 0.0 \\
\hline $\mathrm{Hco3}^{\circ}$ & & $66 \times 10^{-5}$ \\
\hline So $4^{E}$ & & $32 \times 10^{-4}$ \\
\hline $\mathrm{Cl}^{-}$ & & $53 \times 10^{-3}$ \\
\hline Texture & & Loamy sand \\
\hline
\end{tabular}


arranged in a split-plot in a randomized complete block design with three replications. The experimental plots $(4 \times 0.5 \mathrm{~m})$ were under trickle irrigation system throughout the growing season. Three tons of animals anuae/ ha were applied to all plots prior to planting (rate usually used by farmers in the area). Urea was applied at rates of $0,60,120$ and $180 \mathrm{~kg} \mathrm{~N} / \mathrm{ha}$. Halves of these were applied to soil at planting time. The other halves of urea rates alone or in combination with $\mathrm{P}, \mathrm{K}$ or PK were applied to plants either as foliar applications or as soil applications at weekly intervals starting at flowering stage and continued for nine weeks. Details of experimental treatments are shown in table 2. 
Table 2. composition and concentration of nutrient solution applied through foliar or soil to tomato plants.

\begin{tabular}{|c|c|c|c|c|c|c|c|}
\hline \multirow[t]{2}{*}{$\begin{array}{c}\stackrel{\mathscr{\omega}}{\leftrightarrow} \\
\stackrel{\sim}{\ominus}\end{array}$} & \multicolumn{3}{|c|}{$\begin{array}{c}\text { Total nutrient } \\
\text { application }(\mathrm{kg} / \mathrm{ha})\end{array}$} & \multicolumn{3}{|c|}{$\begin{array}{l}\text { Foliar solution Con. } \\
\qquad(\mathrm{mole} / \mathrm{L})\end{array}$} & \multirow[t]{2}{*}{$\begin{array}{l}\text { Method of } \\
\text { application }\end{array}$} \\
\hline & $\mathrm{N}^{*}$ & $\mathrm{P}$ & $\mathrm{K}$ & $\mathrm{N}$ & $\mathrm{P}$ & $\mathrm{K}$ & \\
\hline 1 & 0 & 0 & 0 & - & - & - & - \\
\hline 2 & 60 & 0 & 0 & 0.12 & - & - & Foliar \\
\hline 3 & 120 & 0 & 0 & 0.24 & - & - & Foliar \\
\hline 4 & 180 & 0 & 0 & 0.36 & - & - & Foliar \\
\hline 5 & 60 & 15 & 60 & 0.12 & 0.025 & 0.087 & Foliar \\
\hline 6 & 120 & 15 & 60 & 0.24 & 0.025 & 0.087 & Foliar \\
\hline 7 & 180 & 15 & 60 & 0.36 & 0.025 & 0.087 & Foliar \\
\hline 8 & 60 & 0 & 0 & - & - & - & Soil \\
\hline 9 & 120 & 0 & 0 & - & - & - & Soil \\
\hline 10 & 180 & 0 & 0 & - & - & - & Soil \\
\hline 11 & 60 & 15 & 60 & - & - & - & Soil \\
\hline 12 & 120 & 15 & 60 & - & - & - & Soil \\
\hline 13 & 180 & 15 & 60 & - & - & - & Soil \\
\hline 14 & 0 & 0 & 60 & - & - & 0.087 & Foliar \\
\hline 15 & 0 & 15 & 0 & - & 0.025 & - & Foliar \\
\hline 16 & 0 & 15 & 60 & - & 0.025 & 0.087 & Foliar \\
\hline 17 & 60 & 0 & 60 & 0.12 & - & 0.087 & Foliar \\
\hline 18 & 60 & 15 & 0 & 0.12 & 0.025 & - & Foliar \\
\hline 19 & 120 & 0 & 60 & 0.24 & - & 0.087 & Foliar \\
\hline 20 & 120 & 15 & 0 & 0.24 & 0.025 & - & Foliar \\
\hline 21 & 180 & 0 & 60 & 0.36 & - & 0.087 & Foliar \\
\hline 22 & 180 & 15 & 0 & 0.36 & 0.025 & - & Foliar \\
\hline
\end{tabular}

(*): Sources of N, P and $\mathrm{K}$ are urea, superphosphate and $\mathrm{K}_{2} \mathrm{So}_{4}$, respectively.

Nutrient foliar fertilizer solution were prepared by dissolving desired amount of $\mathrm{N}, \mathrm{P}$ or $\mathrm{K}$ or in combination according to treatments, for each application in 7L of distilled water containing $10 \mathrm{ml}$ of $0.1 \mathrm{gmL}^{-1}$ Tween-80 regulated at $\mathrm{pH}$ 5-6. 
Tomato (Lycopersion escolentum Mill.) seeds cv. supermarmande were planted in middle of Aug. 1993. Each experimental plot contained 32 plants at one meter interval (among experimental plots). Plants were covered by polyethylen tunnels during the cold period from mid Oct. to mid of March.

All spray treatments were applied at 5 P.M. using a $\mathrm{Co}_{2}$ pressurized sprayer. Soil surface was covered by polyethylene sheets during spraying period. Four plants at middle of the row of each treatment were selected and growth parameters: Plant height, No. of flowers, No. of branches and number of fruits were carried out. All studied growth parameter were taken seven days after last fertilizer application. At the end of the season (April 1994) the four selected plants were harvested, dried at $70^{\circ} \mathrm{C}$, and dry weight were recorded. Total yield was determined from all plants in each experimental plot throughout productive period. Early yield was determined as the first three harvesting time of each experimental plot. Analysis of variance of experimental treatments is reported in table 3 .

Table 3. Analysis of variance of experimental treatments. ${ }^{(1)}$

\begin{tabular}{|c|c|c|c|c|c|c|c|c|}
\hline $\begin{array}{l}\text { Sarameter } \\
\text { S.O.V. }\end{array}$ & & $\mathrm{N}$ & $\mathbf{P}$ & $\mathrm{K}$ & NP & NK & PK & NPK \\
\hline \multirow{2}{*}{ Plant height } & Foliar & - & $*$ & NS & 4 & $*$ & NS & $*$ \\
\hline & Soil & $" *$ & - & - & - & - & - & *t \\
\hline \multirow{2}{*}{$\begin{array}{c}\text { No. of } \\
\text { flowers/plant }\end{array}$} & Foliar & NS & $\mathrm{NS}$ & $\mathrm{NS}$ & NS & $\mathrm{NS}$ & $\mathrm{NS}$ & NS \\
\hline & Soil & + & $\cdot$ & $\cdot$ & - & - & $\cdot$ & $\div$ \\
\hline \multirow{2}{*}{ No. of fruits/plant } & Foliar & ** & NS & - & NS & NS & NS & - \\
\hline & Soil & 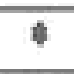 & - & - & - & - & - & * \\
\hline \multirow{2}{*}{$\begin{array}{c}\text { No. of } \\
\text { branches/plant }\end{array}$} & Foliar & NS & 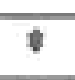 & $*$ & NS & NS & NS & 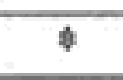 \\
\hline & Soil & $\%$ & - & - & - & - & - & to \\
\hline \multirow{2}{*}{ Dry weight } & Foliar & 6 & NS & *t" & $\%$ & \#* & $\mathrm{NS}$ & $\#$ \\
\hline & Soil & 60 & - & - & $\cdot$ & - & - & $\%$ \\
\hline \multirow{2}{*}{ Early yield } & Foliar & 60 & NS & - & NS & * & NS & 60 \\
\hline & Soil & "* & - & - & - & - & - & 60 \\
\hline \multirow{2}{*}{ Total yield } & Foliar & $" *$ & NS & "\# & $\%$ & $\mathrm{NS}$ & $\circ$ & 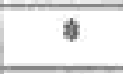 \\
\hline & Soil & 6 & - & - & - & - & - & $\%$ \\
\hline
\end{tabular}

* : Significant differences at the 0.05 probability level.

**: Significant differences at the 0.01 probability level.

(1): See table (2) for the details of experimental treatments. 


\section{RESULTS}

Growth parameters:

Data in table 4 shows that foliar or soil application of $\mathrm{N}$ or NPK significantly affected plant height and number of flowers, fruits and branches / plant as compared to control plants. Foliar application of solution contained 0.12 mole N/L alone or in combination with $P$ $(0.025 \mathrm{~mole} \mathrm{P} / \mathrm{L})$ and $\mathrm{K}$ (0.087 mole $\mathrm{K} / \mathrm{L})$ significantly increased plant height and number of fruits / plant, but had little effect on number of flowers and branches / plant. However, increasing $\mathrm{N}$ concentration in spray solution to 0.24 or 0.36 mole $\mathrm{N} / \mathrm{L}$ significantly decreased plant height and number of flowers, fruits and branches / plant.

Spray application that contained only 0.025 mole $\mathrm{P} / \mathrm{L}, \mathrm{K}$ $(0.087 \mathrm{~mole} \mathrm{~K} / \mathrm{L})$ or PK at different nitrogen rates $(0.12,0.24$ or 0.36 mole N/L) did not significantly affect number of flowers, fruits or branches / plant. However, the lowest plant height was produced by plants sprayed with solutions of $\mathrm{P}, \mathrm{K}$ or PK contained $0.36 \mathrm{~mole} \mathrm{~N} / \mathrm{L}$ (table 5).

As of soil fertilization the results (table 4) showed that highest plant height and number of flowers, fruits and branches / plant were obtained when plants were Supplied with $120 \mathrm{~kg} \mathrm{~N} / \mathrm{ha}$

Table 4. Effect of application method of No or NPK on growth parameters of tomato plant.

\begin{tabular}{|c|c|c|c|c|c|c|c|c|c|}
\hline Growvith Parameters & $\begin{array}{c}\text { Application } \\
\text { method }\end{array}$ & Con. & N60 & $\mathrm{N} 120$ & N180 & Con. & NGOPK & NI20PK & NI801'K \\
\hline \multirow{2}{*}{ Plant height (cru) } & Foliar & $60.33 \mathrm{c}$ & $67.91 \mathrm{a}$ & 64.916 & $62.25 \mathrm{bc}$ & $60.33 \mathrm{~b}$ & $79.6 \mathrm{a}$ & $61.0 \mathrm{~b}$ & $51.0 \mathrm{c}$ \\
\hline & Soil & $60.33 \mathrm{~b}$ & $81^{*} .00 \mathrm{a}$ & $100^{\circ} .60 \mathrm{a}$ & $64.60 \mathrm{~b}$ & $60.33 \mathrm{~b}$ & $60.0 \mathrm{a}$ & $78.0 \mathrm{a}$ & $63.6 \mathrm{~b}$ \\
\hline \multirow{2}{*}{$\begin{array}{c}\text { No. of } \\
\text { fuwcrs/plaint }\end{array}$} & Foliar & $18.33 \mathrm{a}$ & $20.00 \mathrm{a}$ & $17.41 \mathrm{a}$ & $16.75 \mathrm{a}$ & $18.33 \mathrm{a}$ & $15,33 \mathrm{a}$ & $14.33 \mathrm{a}$ & $14,33 \mathrm{a}$ \\
\hline & Soil & 18.336 & $50^{\circ} .00 \mathrm{a}$ & $45^{\circ} .66 \mathrm{a}$ & $23.66 \mathrm{~b}$ & $18.33 \mathrm{a}$ & $39 \cdot .0 \mathrm{a}$ & $25^{\circ} .66 \mathrm{a}$ & $31^{\bullet}, 33=$ \\
\hline \multirow{2}{*}{ No, of fruits/plants } & Foliat & $9.00 \mathrm{~b}$ & $17.91 \mathrm{a}$ & $13.91 \mathrm{a}$ & 8.336 & $9.00 \mathrm{~b}$ & $32.33 \mathrm{a}$ & $15.00 \mathrm{~b}$ & $10.66 \mathrm{~b}$ \\
\hline & Soil & $9.00 c$ & $26.66 \mathrm{ab}$ & $20 \cdot .66 \mathrm{a}$ & $19 \cdot .00 \mathrm{~b}$ & $9.00 \mathrm{c}$ & $29.33 \mathrm{ab}$ & $36.33 \mathrm{a}$ & $25.33 \mathrm{~b}$ \\
\hline \multirow{2}{*}{$\begin{array}{c}\text { No. of } \\
\text { Irauchessplant }\end{array}$} & Foliar & $4.00 \mathrm{a}$ & $6.33 \mathrm{z}$ & $6.33 \mathrm{a}$ & $5.66 \mathrm{a}$ & $4.00 \mathrm{~b}$ & $7.6 \mathrm{a}$ & $5.0 \mathrm{~b}$ & $5.33 \mathrm{~b}$ \\
\hline & Suil & $4.00 \mathrm{c}$ & $8.66 \mathrm{ab}$ & $9.33 \mathrm{a}$ & $6.33 \mathrm{bc}$ & $4.00 \mathrm{~b}$ & $8.66 \mathrm{a}$ & 90.63 & $9.0^{\circ} \mathrm{a}$ \\
\hline
\end{tabular}

$\left({ }^{\circ}\right)$ : Significant difference between two methods according to ( $(1)$ test. Rowe followed by the stume leller are non significant at llie 0.05 probability level. 


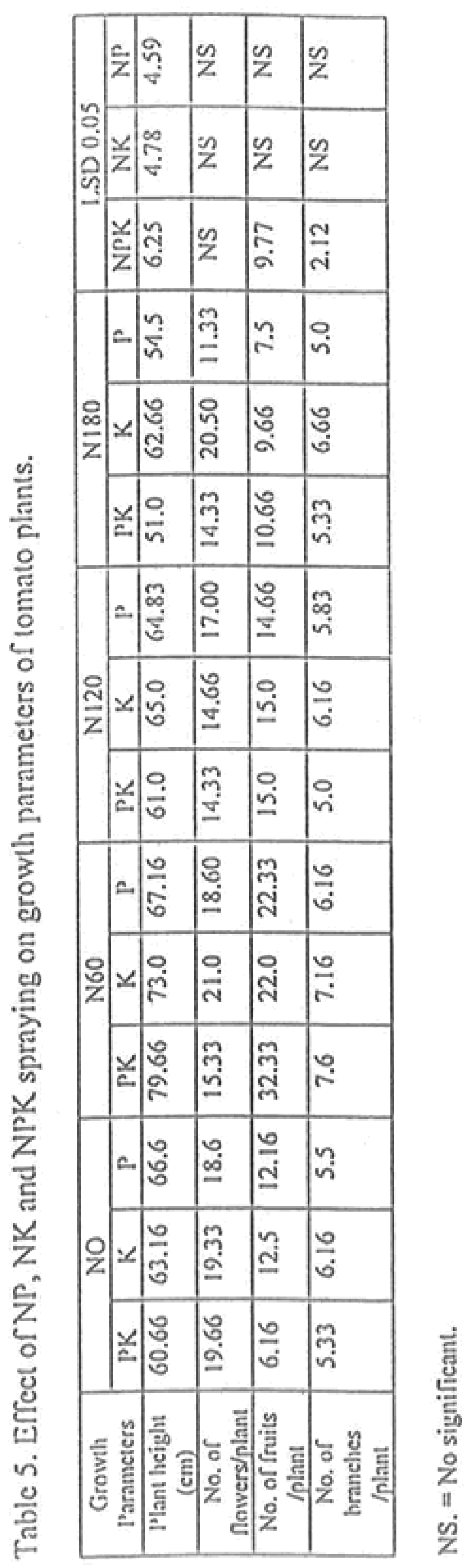


alone or in combination with $\mathrm{p}(15 \mathrm{~kg} \mathrm{P} / \mathrm{ha})$ and $(60 \mathrm{~kg} \mathrm{~K} / \mathrm{ha})$. The lowest values of these growth parameters were associated with plant receiving $180 \mathrm{~kg} \mathrm{~N} / \mathrm{ha}$.

Data in table 4 shows that most, but not all, of the foliar treatments resulted in smaller growth parameters relative to their respective soil treatments.

Dry weight:

Dry weight of plants was significantly increased by foliar or soil application of N or NPK relative to control plants (fig. 1). Spray application that contained different $\mathrm{N}$ concentrations did not significantly affect dry weight produced by treated plants. Nevertheless, dry weight of plants sprayed with solution containing 0.12 mole $\mathrm{N} / \mathrm{L}$ showed slightly higher value $(182.6 \mathrm{~g} / \mathrm{plant})$ than those sprayed with foliar application containing 0.24 or $0.36 \mathrm{~mole} \mathrm{~N} / \mathrm{L}$ (avarage of $175.5 \mathrm{~g} /$ plant). This differences in dry weight production between $\mathrm{N}$ concentrations of $0.12 \mathrm{~mole} \mathrm{~N} / \mathrm{L}$ and those of 0.24 or $0.36 \mathrm{~mole}$ $\mathrm{N} / \mathrm{L}$ became significant when $0.025 \mathrm{~mole} \mathrm{P} / \mathrm{L}$ and 0.087 mole $\mathrm{K} / \mathrm{L}$ were combined with $\mathrm{N}$ in spray solutions.

Fig. 2 illustrates that application of solutions containing 0.025 mole $\mathrm{P} / \mathrm{L}, 0.087$ mole $\mathrm{K} / \mathrm{L}$ or $\mathrm{PK}$ alone or in combination with different $\mathrm{N}$ concentrations significantly increased dry weight as compared to control plants which produced dry weight of $109.8 \mathrm{gm} /$ plant. The results also showed that addition of $\mathrm{N}$ to spray solutions containing $\mathrm{P}, \mathrm{K}$ or $\mathrm{Pk}$ had a significant effect on dry matter production as compared to solutions contained only $\mathrm{P}, \mathrm{K}$ or PK. The dry weight significantly decreased as $\mathrm{N}$ in foliar solution of $\mathrm{P}, \mathrm{K}$ or PK. The dry weight significantly decreased as $\mathrm{N}$ in foliar solution of $\mathrm{P}, \mathrm{K}$ or PK increased from 0.12 mole $\mathrm{N} / \mathrm{L}$ to $0.36 \mathrm{~mole} \mathrm{~N} / \mathrm{L}$.

As far as soil fertilizations is concerned, Fig. 1 shows that the highest dry weight was produced by plants receiving $120 \mathrm{~kg} \mathrm{~N} / \mathrm{ha}$ (210 gm / plant) as compared to those of $60 \mathrm{~kg}$ $\mathrm{N} / \mathrm{ha}$ (196 gm / plant) or $180 \mathrm{~kg} \mathrm{~N} / \mathrm{ha}$ (187 gm / plant). However, when $15 \mathrm{~kg} \mathrm{P} / \mathrm{ha}$ and $60 \mathrm{~kg} \mathrm{~K} / \mathrm{ha}$ were mixed with $\mathrm{N}$, then the effect of $\mathrm{N}$ rates on dry matter production was diminished. 


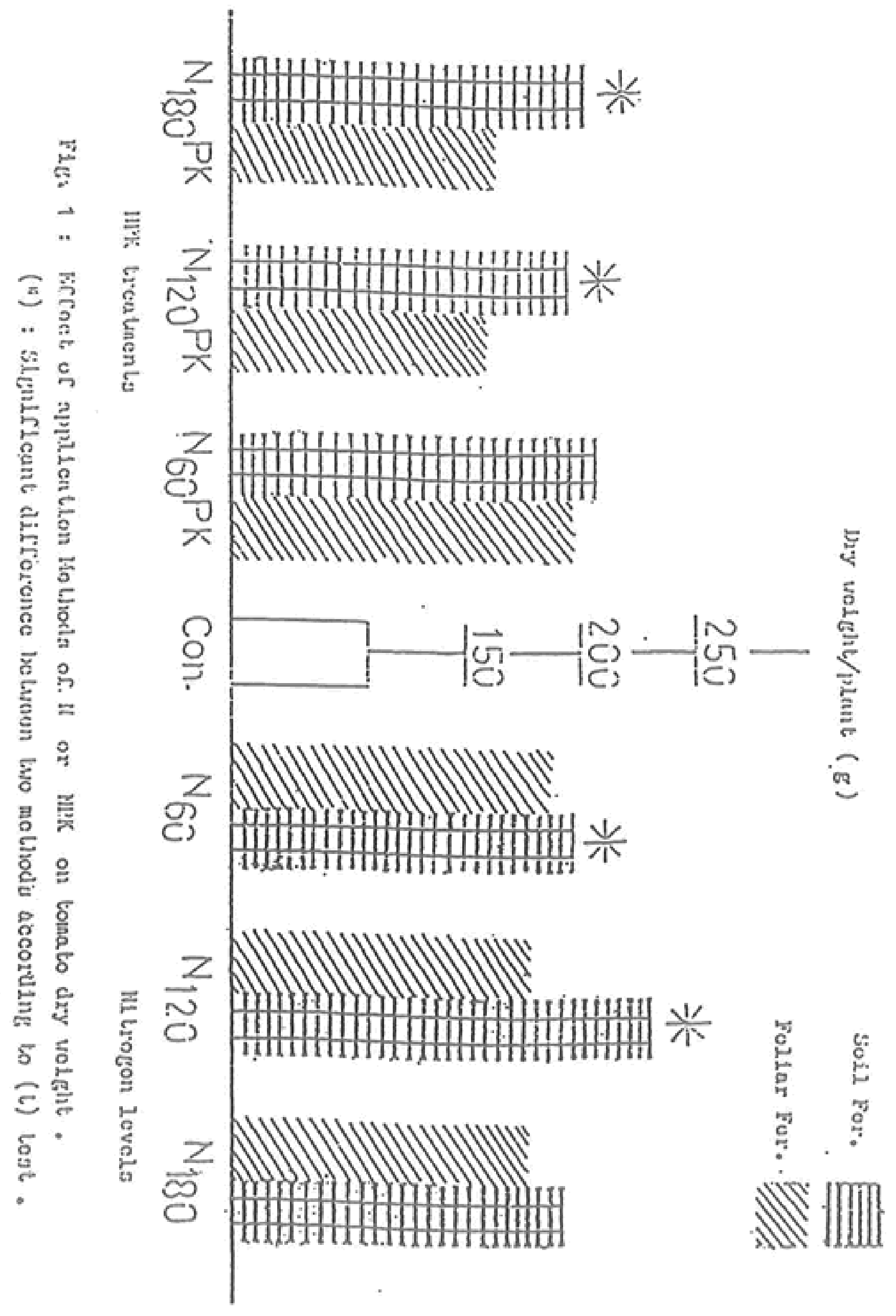




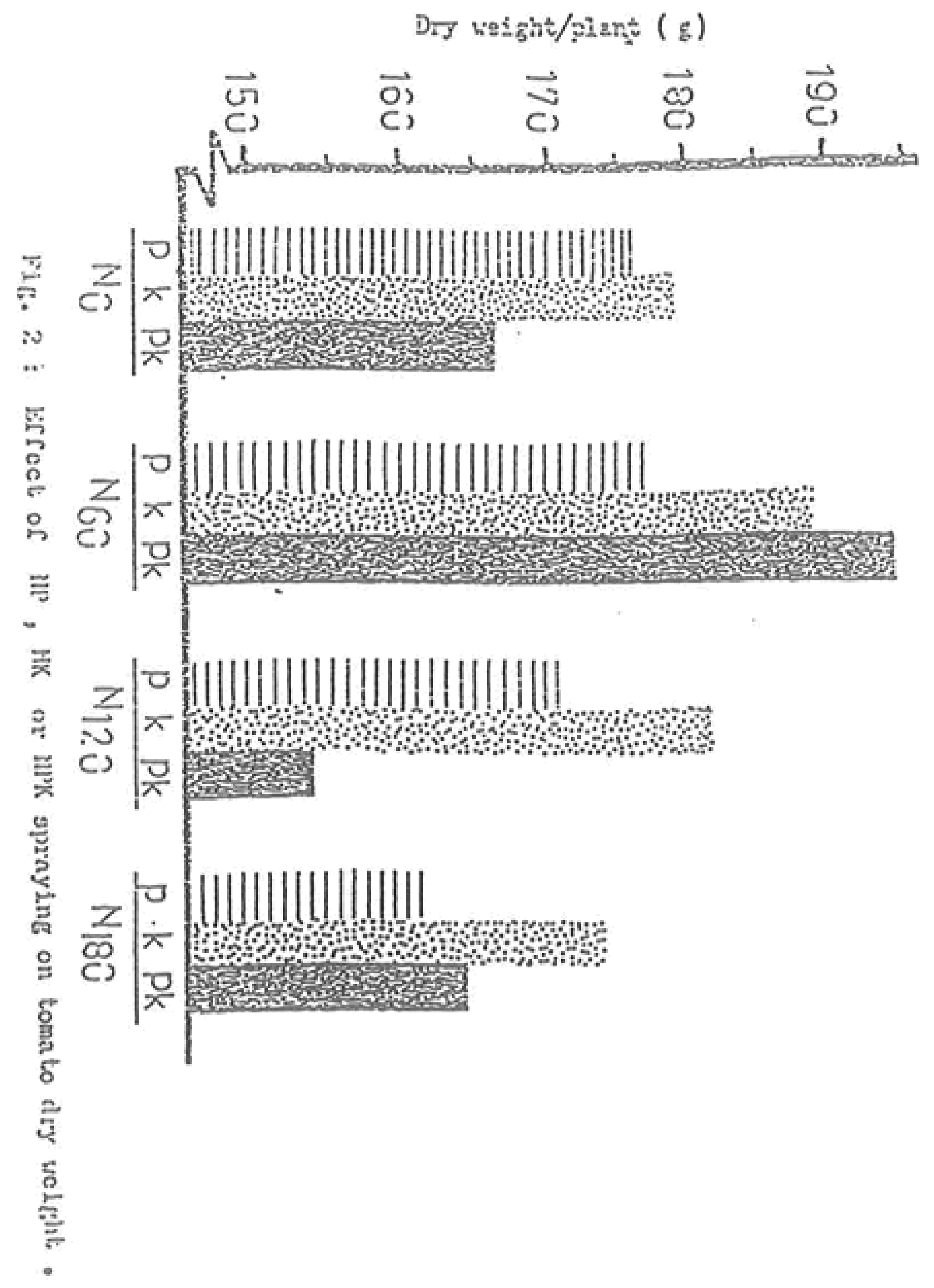


Data in fig. 1 show that most, but not all, soil-fertilized plants produced dry matter higher than those of their respective foliar fertilization treatments. It is important, however, to emphasize that dry weight produced by plants receiving $60 \mathrm{~kg}$ $\mathrm{N} / \mathrm{ha}(0.12 \mathrm{~mole} \mathrm{~N} / \mathrm{L})$ only or in combination with PK through foliar fertilization did not significantly differ from those produced by plants receiving 120 or $180 \mathrm{~kg} \mathrm{~N} / \mathrm{ha}$ alone or in combination with PK through soil fertilization.

\section{Early Yield:}

Data in table 6 show that, regardless of $\mathrm{N}$ concentration in spray solution, spraying plants with solution containing $\mathrm{N}$ alone or NPK resulted in significantly higher yield as compared to respective plants of soil fertilization treatments. However, increasing $\mathrm{N}$ concentration in spray solution from 0.12 to 0.36 mole / L decreased early yield from $24.78 \%$ to $17.99 \%$ when solution contained $\mathrm{N}$ alone and from $25.10 \%$ to $20.24 \%$ when solution contained NPK.

Table 6. Effect of application methods of $\mathrm{N}$ or NPK on early yield (\% of total yield) of tomato plants.

\begin{tabular}{|c|c|c|c|c|c|c|c|c|}
\hline $\begin{array}{c}\text { Application } \\
\text { Method }\end{array}$ & Con. & N60 & NI20 & N180 & Con. & N60PK & N120PK & N180PK \\
\hline & & $\bullet$ & $\bullet$ & $\bullet$ & & $\bullet$ & $\bullet$ & $\bullet$ \\
\hline Foliar & $16.00 \mathrm{~b}$ & $24.78 \mathrm{a}$ & $24.09 \mathrm{a}$ & $17.99 \mathrm{~b}$ & $16.00 \mathrm{~b}$ & $25.1 \mathrm{a}$ & $26.95 \mathrm{a}$ & $20.24 \mathrm{~b}$ \\
\hline Soil & $16.00 \mathrm{a}$ & $13.31 \mathrm{~b}$ & $12.16 \mathrm{~b}$ & $10.49 \mathrm{c}$ & $16.00 \mathrm{a}$ & $15.83 \mathrm{a}$ & $16.59 \mathrm{a}$ & $16.67 \mathrm{a}$ \\
\hline
\end{tabular}

$\left({ }^{*}\right)$ : $\quad$ Significant difference between two methods according to $(t)$ test. Rows followed by the same letter are non significant at the 0.05 probability level.

Total Yield:

Nitrogen application alone or in combination with PK through soil or foliar to plants significantly increased total yield production as compared to control plants. The yield increase, however, depended on rates of nitrogen and methods of application. Data in table 7 showed that foliar application of solution contained $0.12 \mathrm{~mole} \mathrm{~N} / \mathrm{L}$ resulted in highest total yield (22.756 tons / ha) compared with other $\mathrm{N}$ concentrations. Increasing $\mathrm{N}$ concentration in spray solution to 0.24 or 0.36 mole / L decreased total yield to 20.631 and 19.837 ton/ha, respectively. 

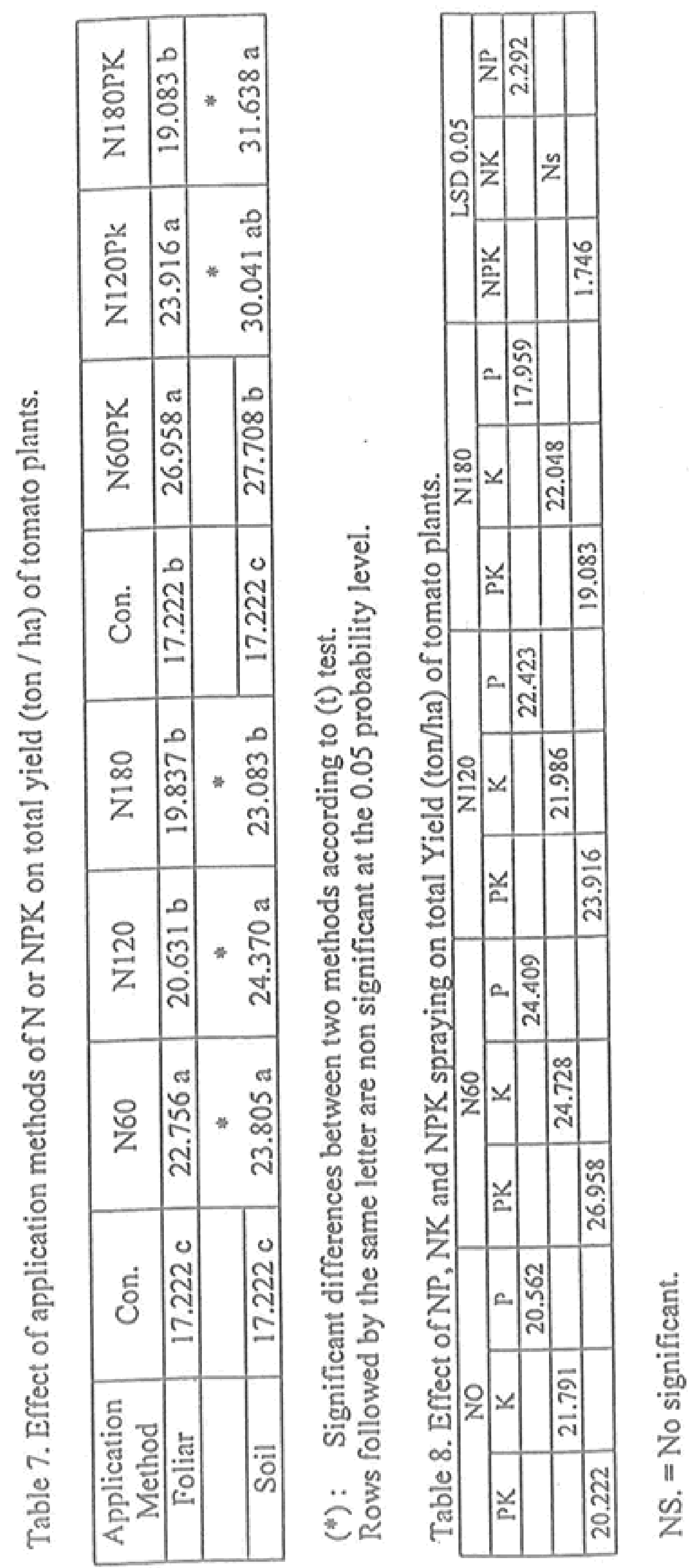
Plants treated with foliar solution containing $0.12 \mathrm{~mole} \mathrm{~N} / \mathrm{L}, 0.026$ mole $\mathrm{P} / \mathrm{L}$ and $0.087 \mathrm{~mole} \mathrm{~K} / \mathrm{L}$ produced total yield of 26.958 ton/ha. Increasing $\mathrm{N}$ concentration in NPK spray solution to 0.24 and 0.36 mole/L decreased total yield to 23.916 and 19.083 ton/ha, respectively.

Data in table 8 show that application of spray solution contain mole $\mathrm{P} / \mathrm{L}$ or $0.087 \mathrm{~mole} \mathrm{~K} / \mathrm{L}$ alone or in combination with different concentrations of $\mathrm{N}$ resulted in significant total yield increases as compared to control plants, which produced a total yield of 17.222 tons/ hg. The addition of $\mathrm{N}$ to spray solution containing $\mathrm{P}$ produced significant effect on total yield production. Therefore, addition of spray solution containing $0.12 \mathrm{~mole} \mathrm{~N} / \mathrm{L}$ and $0.025 \mathrm{~mole} \mathrm{P} / \mathrm{L}$ increased total yield from 20.562 tons/ha. (produced by spray solution containing $0.025 \mathrm{~mole} \mathrm{P/L}$ alone) to 24.409 tons $/ \mathrm{ha}$. Moreover, increasing $\mathrm{N}$ concentration in spray solution containing $0.025 \mathrm{~mole} \mathrm{P} / \mathrm{L}$ to $0.36 \mathrm{~mole} / \mathrm{L}$ decreased total yield production to 17.959 ton/ha. Data also indicated that addition of $\mathrm{N}$ to spray solution contained $0.087 \mathrm{~mole} \mathrm{~K} / \mathrm{L}$ did not significantly affect total yield production by plant as compared to that of plants treated with spray solution containing K only.

As for soil fertilization, increasing $\mathrm{N}$ rate from 60 to 120 $\mathrm{kg} / \mathrm{ha}$ increased yield from 23.805 to 24.370 tons/ha. Increasing $\mathrm{N}$ rate further to $180 \mathrm{~kg} /$ ha decreased total yield to 23.083 tons $/$ ha. When $\mathrm{N}$ was combined with $15 \mathrm{~kg}$ P/ha and $60 \mathrm{~kg} \mathrm{~K} /$ ha highest yield was obtained with $180 \mathrm{~kg} \mathrm{~N} / \mathrm{ha}(31.638 \mathrm{tons} / \mathrm{ha})$ which was not significantly different from yield of plant receiving $120 \mathrm{~kg} \mathrm{~N} / \mathrm{ha}$ (30.041 tons/ha). The results also indicated that plants of soil fertilization treatments produced total yield higher than those of their respective treatments of foliar fertilization. It is worthwhile to indicate that differences in total yield production due to methods of depend on $\mathrm{N}$ concentration in spray solution. The higher the $\mathrm{N}$ concentration in spray solutions, the higher the differences in total yield production due to methods of fertilizers application.

\section{DISCUSSION}

The results obtained from this study demonstrated that tomato growth and yield were significantly increased by nitrogen fertilizer 
(alone or in combination with PK), regardless if application methods (soil or foliar spray). However, the magnitude of growth response to $\mathrm{N}$ fertilizer depended on application methods. In most, but not all treatments, the growth parameters and yield response to foliar application were consistently lower compared to their respective soil application treatments. These results are in accordance with those reported by Silberstein and Wittwer (1951), Hamar and Ver (1972) and Bestvater and Calver (1975) for greenhouse and field grown tomato. On the other hand, Antonio (1984), kastori et al. (1987) and Sarhan (1979) reported significant increases in growth and yield of tomato plants sprayed with foliar solution containing N or NPK. It is worthwhile to mention that differences in plant response due to methods of N or NPK application obtained in this study depended on $\mathrm{N}$ rate or concentration in spray solutions. The data in fig. 1 showed that generally dry matter production by plants receiving $60 \mathrm{~kg} \mathrm{~N} / \mathrm{ha}$ (0.12 mole N/L) only or in combination with Pk through foliar spray did not significantly differ from those produced by plants treated with 120 or $180 \mathrm{~kg} \mathrm{~N} / \mathrm{ha}$ through soil fertilization. As $\mathrm{N}$ concentrations in spray solution increased from $0.12 \mathrm{~mole} / \mathrm{L}$ (60 $\mathrm{kg} / \mathrm{ha}$ ) to $0.36 \mathrm{~mole} / \mathrm{L} 9180 \mathrm{~kg} / \mathrm{ha}$ ) the differences in dry weight production due to application methods increased. Moreover, data in Table 7 clearly indicated that differences in total yield production due to method of application depend on $\mathrm{N}$ concentration in spray solution, since it decreased from 12.55 ton/ha when plant received $180 \mathrm{~kg} \mathrm{~N}+\mathrm{PK} / \mathrm{ha}(0.36 \mathrm{~mole} \mathrm{~N} / \mathrm{L})$ to 0.750 ton $/ \mathrm{ha}$ as $\mathrm{N}$ rate decreased to $60 \mathrm{~kg} \mathrm{~N} / \mathrm{ha}(0.12 \mathrm{~mole} \mathrm{~N} / \mathrm{L})$.

Tomato plants sprayed with solution containing 0.24 mole $\mathrm{N} / \mathrm{L}(120 \mathrm{~kg} \mathrm{~N} / \mathrm{ha})$ or $0.36 \mathrm{~mole} \mathrm{~N} / \mathrm{L}(180 \mathrm{~kg} \mathrm{~N} / \mathrm{ha})$ showed greater visual leaf injury than those appeared on plants receiving 0.12 mole $\mathrm{N} / \mathrm{L}$ (60 kg N/ha); thus, growth and yield may have been influenced primarily by leaf injury associated with foliar fertilization. Similar results were obtained by Rubarston et al. (1977) and Garcia and Hanway (1977) for soybean and Harder et al. (1982) for corn and Bestvater and Calvar (1975) for tomato plants. Below et al. (1984) reported that any increase in photosynthetic activity resulting from urea spray may be negated by leaf burn resulting from foliar spray of urea. Other possible reason is that in soil application method nitrogen fertilizers (alone or in combination with PK) were spliced into nine doses applied weekly during the growing season rather than applying 
them in one or two doses early in the season. This splicing of fertilizer application may have increased the efficiency of $\mathrm{N}$ by reducing it's losses through volatilization, leaching, or denitrification, the processes which normally decreased $\mathrm{N}$ recovery by crops.

Although results obtained from this study do not support the use of foliar application of N or NPK to increase total yield as compared to soil application, foliar application of these fertilizers significantly increased early yield of tomato plants. This early yield increase could be of economical value for tomato producers in the area of study.

Obviously, it would have been desirable to repeat the experiment over two growing seasons or carry it at different locations. However, the time limit and potential cost made this impossible. In spite of these limitation, which should be recognized when examining data reported here, data presented in this paper give a good indication of the effect of foliar fertilization on yield of tomato plant in the area of study.

\section{REFERENCES}

Abdul, K.S. 1978. An investigation of the interaction between mineral nutrition, light and temperature on the growth of tomato plants. Zanco, S (A). 4: 85-98.

Altman, D.W., W.L. McCuistian, and W.E. kronstad, 1983. Grain protein percentage, kernel hardncess and grain yield of winter wheat with foliar applied urea. Agron. J. 75:87-91.

Antonio, J.R. 1984. Effect of urea spray on growth and yield of tomato. Central Luzon State Univ. Sci. J. (Philippines). Nov. 1984 - Oct. 1985. 6(1) P. 174.

Below, F.E., R.J. Lombert, and R.H. Hageman. 1984. Foliar application of nutrients on maize. II. Physiological responses. Agron. J. 76 : 777-784. 
Bestvater, C.R. and D.J. Calvar. 1975. Foliar nutrition of tomatoes. Investing - acion Agropecuaria (summary in English). 1:1-3.

Black, C. A. (edi.) 1965. Methods of soil analysis, part 1 and 2. Am. Soc. Agron. Inc. publisher, Madison, Wisconsin, U.S.A.

Das, R.C. and R.S. Patro. 1989. Effect of micronutrient mixed and urea on growth, yield and quality of tomato (Lycopersicon esculentum Mill.). Orissa J. Hort. 17:37-45.

Fenn, L. B. and D.E. Kissel. 1975. Ammonia volatilization from surface application of $\mathrm{NH}_{4}$-compounds on calcarious soils: IV. Effect of $\mathrm{CaCo} 3$ content. Soil Sci. Soc. Amer. Proc. 39 : 631-633.

Garcia, R. and J.J. Hanway. 1976. Foliar fertilization of soybeans during the seed - filling period. Agron. J. 68: 653-657.

Hamar, N. and R. Ver. 1972. Foliar nutrition experiments with greenhouse tomatoes. Paradiesom-lombtragyazasi kiserletek novenyhazb Zoldsegtermesztesi Kutato Intezet Bulletinje. 7 27-32. (Summary in English).

Harder, H.J., R.E. Carlsonn and R.H. shaw. 1982. Corn grain yield and nutrient response to foliar fertilizer applied nitrogen during grain fill. Agron. J. 74: 106-110.

Kastori, R., N. petrovic and M. Ubavic. 1987. Effect of foliar application of the complex crystaline fertilizer "Plantazor" on the yield of some vegetable crops. Agrohemija. 2:153 160.

Malakondaiah, N. and G. Rajeswararao. 1979. Effect of foliar application of phosphorus on growth and mineral composition in peanut plants (Arachis hypogaea L.) under salt - stres. Plant and soil 52: 41-48.

Malakondaiah, N., N.M. safays and M.K. wali. 1981. Response of alfalfa and barley to foliar application of $\mathrm{N}$ and $\mathrm{p}$ on coal mine soil. Plant and Soil. 59: 441-453. 
Roberston, W.K., K. Hinson and L.C. Hammond. 1977. Foliar fertilization of soybean (Glycine maxel.) Merr.) in Florida. Soil Crop. Sci. soc. Fla. Proc. 36:77 - 79.

Sarhan T.Z. 1979. Effect of nitrogen rates, with or without foliar fertilization, on yield and quality of two varieties of tomato plants. M.Sc. Thesis. Sulaymania Univ. Iraq. (In Arabic).

Sesay, A. and R. shibles, 1980. Mineral depletion and leaf senescence in soybean as influenced by foliar application during seed filling. Ann. bot. 45:47-55.

Silberstein, O. and S.H. Wittwer. 1951. Foliar application with phosphatic nutrients on vegetable crops. Proc. Amer. Soc. Hor. Sci. 58:179-190.

Thom, W.O., T.C. Miller and D.H. bowman. 1981. Foliar fertilization of rice after midseason. Agron. J. 73:411-414.

Tomar, J.S., A.F. Mackenzie, G.R. Mehuys and I. Alli. 1988. Corn growth with foliar nitrogen, soil-applied nitrogen, and legume intercrops. Agron. J. 80: 802-807.

Widders, I.E. 1991. Absorption and translocation of foliar applied triazone $\mathrm{N}$ as compared to other nitrogen sources in tomato. J. Plant Nutri. 14:1035 - 1045. 
تأثير إضافة النتروجين منفرداً أو متالخلأ مع الفسفور والبوتاسيوم بالرش أو إلى التربة على نمو نبات الطماطم .

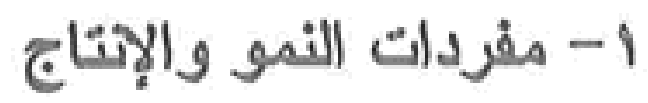

محمد عبداله عبدالكريم و عبدالمهدي صالح الانصاري قسم التربة واستصلاح الأراضي - كلية الزراعة - جامعة البصرة - العراق

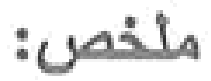

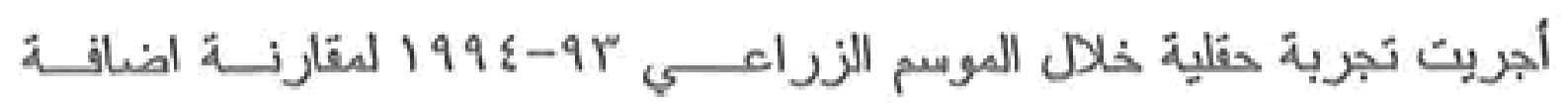

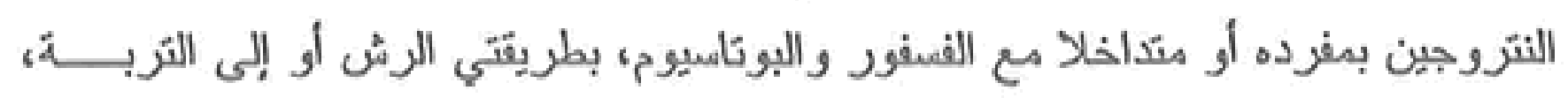

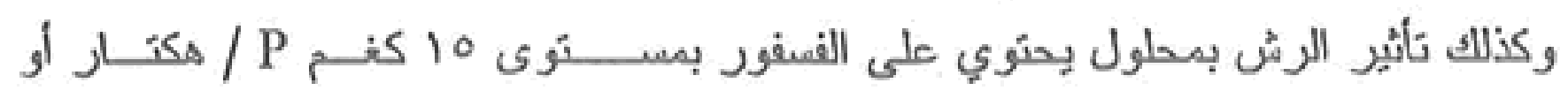

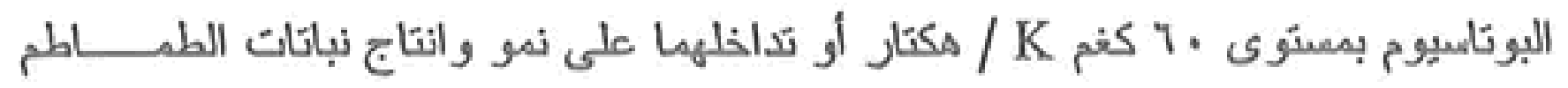

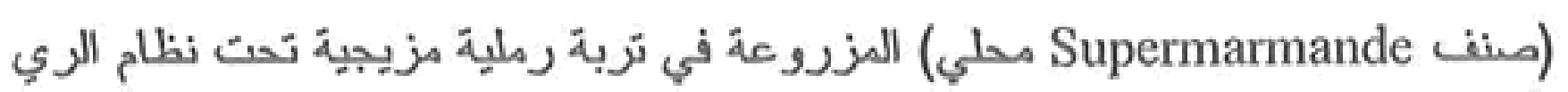

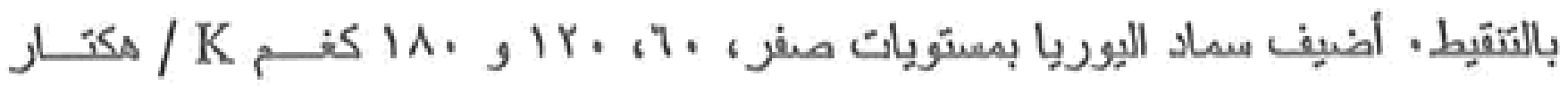

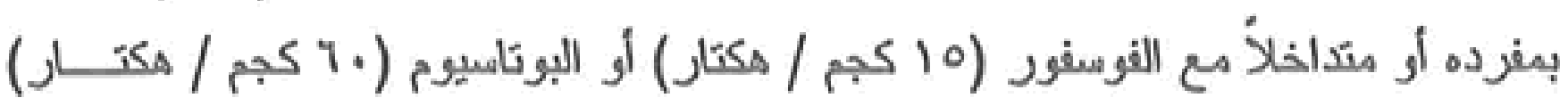

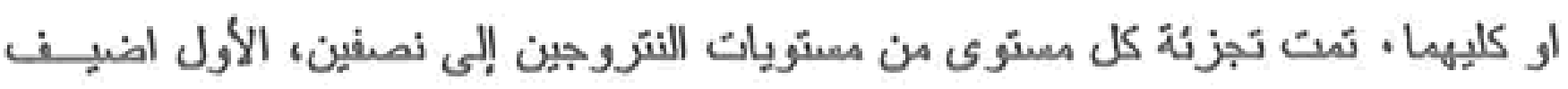

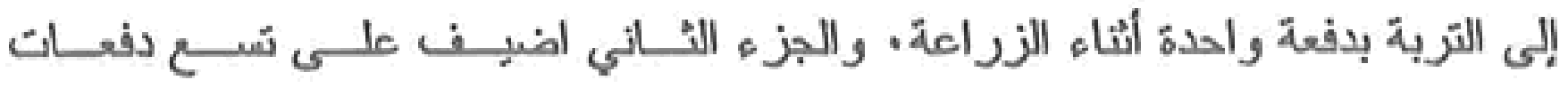

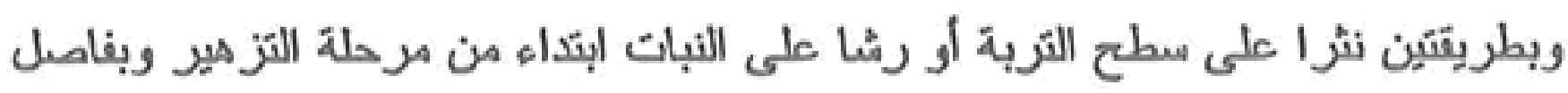

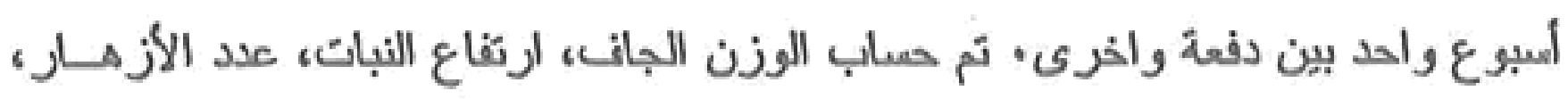

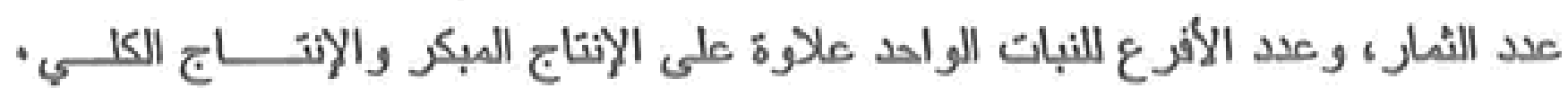

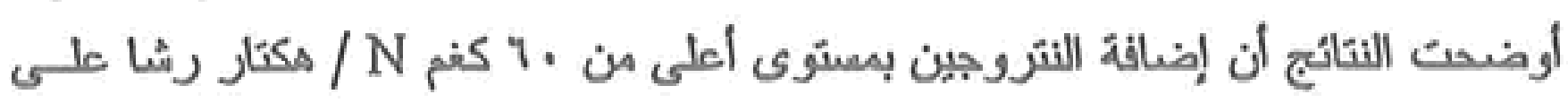

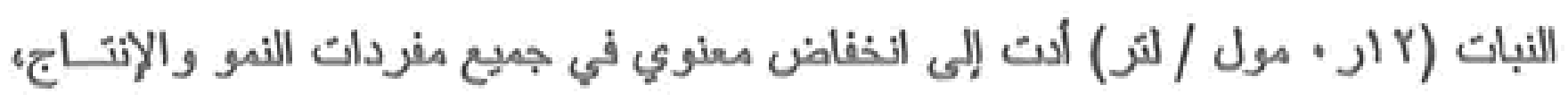

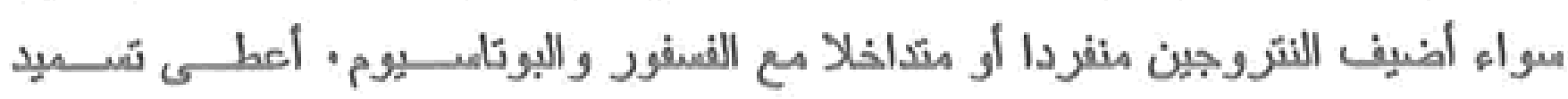

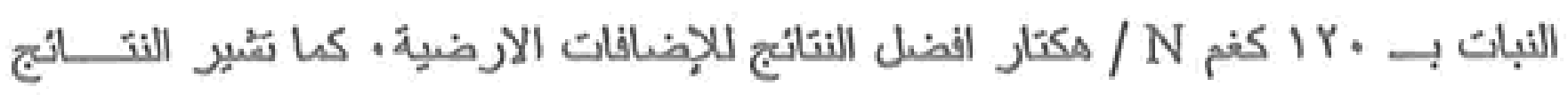

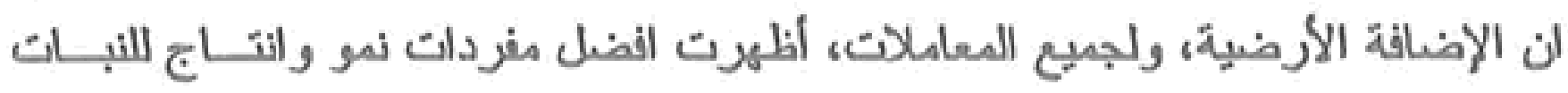

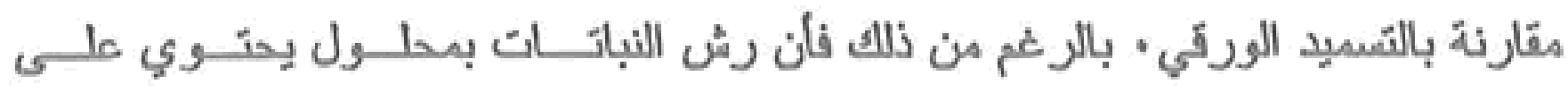

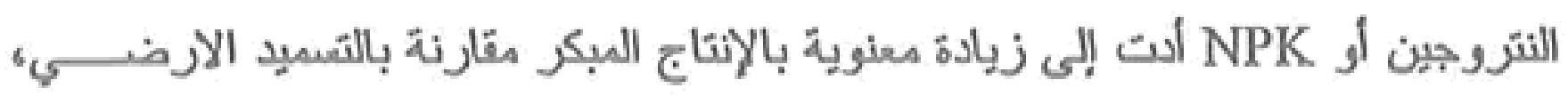

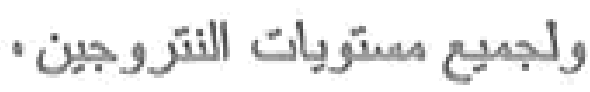

